\title{
GREEN FINANCE FOR SUSTAINABLE GROWTH, THE CASE OF CROATIA*
}

\author{
Tomislav Ridzak ${ }^{* *}$ \\ Ante Žigman ${ }^{* * *}$
}

\begin{abstract}
Sustainable investments make a growing and important share of total assets under management in the fund management industry. Except for investor preferences, a significant driver of demand for sustainable assets will also be the new European plan for sustainable finance. The goal of the plan is to reorient capital towards a more sustainable economy by incentivizing financial intermediaries to offer more sustainable investment products. This paper aims to assess the EU plan for sustainable finance and explain its implications on the financial system and the economy of a small member state, using Croatia as an example. In addition to that, we also present policy advice for policymakers that want to use the European plan for sustainable finance to make their economy (more) sustainable. We find that although the plan is broad and ambitious, to ensure its overall success some additions and tweaks at the national level could be needed. First, including pension plans as one of the biggest investors in many EU member states would increase overall plan impact. Second, national-level regulation about non-financial (sustainability) data for listed companies might be beneficial. Without such regulation, obtaining data directly from corporations might result in non-comparable reports or missing data. In the second step, this could undermine the plan's overall goals.
\end{abstract}

KEYWORDS: sustainable investments, non-bank financial institutions, Croatia

\footnotetext{
* The views expressed in this article are those of the authors and do not necessarily represent official position of Croatian Financial Services Supervisory Agency.

** Tomislav Ridzak, Croatian Financial Services Supervisory Agency, Zagreb, Croatia; tomislav.ridzak@hanfa.hr.

*** Ante Žigman, Croatian Financial Services Supervisory Agency, Zagreb, Croatia; ante.zigman@hanfa.hr.
} 


\section{INTRODUCTION}

Sustainable investments are a new hot topic in the world. Since it is recognized that we cannot deny climate changes, it became necessary to act against them. One of the ways how to tackle climate changes, while at the same time encourage economic growth, is to promote investing in projects that are environmentally friendly, socially responsible, and innovative.

Sustainable investments seem to sell well. The data from the Global Sustainable Investment Review ${ }^{1}$ shows that the sustainable investments in five major regions (Europe, United States, Japan, Canada, Australia, and New Zealand) have increased by $34 \%$ in 2018 compared to $2016 .^{2}$ At the same time, the share of retail investors in total sustainable investing assets increased from 20 to $25 \%$, while the share of professionals dropped, which also corroborates the attractiveness of this type of investment.

The reason behind this surge in sustainable investing can be linked with the changing preferences of investors and changed attitudes towards sustainability issues. As $\mathrm{UBS}^{3}$ puts it, “...technology is enabling greater awareness of global economic and social issues. These global problems are making people of all age groups increasingly keen to find solutions".

Sustainable investments today make an important share of total assets under management. Data for 2018 shows that $49 \%$ of total assets under management in Europe, 26\% in the United States, 51\% in Canada, 63\% in Australia and New Zealand, and 18\% in Japan are designated as sustainable. Across regions, the proportion of sustainable investments is increasing, with the except for Europe, where the share of sustainable investment strategies has decreased, probably due to stricter standards. ${ }^{4}$ Standards are the key element of any green investment in the long run, as we will show in this paper.

In 2018 the European Union has started to work on the plan to make the European economy more sustainable (EC 2018 plan). ${ }^{5}$ The non-bank financial sec-

\footnotetext{
1 GSIA: Global Sustainable Investment Review, [http://www.gsi-alliance.org/wp-content/ uploads/2019/06/GSIR_Review2018F.pdf], 2018,p. 8.

2 Growth rate of sustainable investments recorded from 2014 to 2016 was lower, but still sizable ( 25 per cent).

3 UBS: Millennials - the global guardians of capital, UBS Chief Investment Office, Wealth Management white paper, [https://www.ubs.com/global/en/wealth-management/chief-investment-office/market-insights/digital-disruptions/2017/millennials.html], 2017, p. 28.

4 GSIA: Global Sustainable Investment Review, [http://www.gsi-alliance.org/wp-content/ uploads/2019/06/GSIR_Review2018F.pdf], 2018,p. 9.

5 EC: Action Plan: Financing Sustainable Growth, [https://eur-lex.europa.eu/legal-content/ EN/TXT/PDF/?uri=CELEX:52018DC0097\&from=ENg, 2018. More on renewed sustainable
} 
tor has a prime role in that plan. Today, even though the EC 2018 plan is still not in action and although some implementing acts are still to be discussed, all major building blocks of the plan have been agreed upon. It is expected that the EC 2018 plan will start to become operational from March 2021. This paper will aim to explain the implications of this new EU 2018 plan on the economy and financial system of a small member state, using Croatia as an example.

The paper is divided into seven sections. After the introduction, the next section briefly presents the survey of related literature. Then we show how sustainable investments are done now, before the implementation of the EC 2018 plan. The fourth section presents the main pillars of the EU sustainable finance package and its expected channels of impact on the domestic financial system and financing of the economy. The fifth section investigates the potential for implementing sustainable policies in the Croatian non-bank financial sector. The sixth section focuses on issuers of financial instruments and their role in the EU sustainable finance action plan. Finally, the last section contains conclusions.

\section{RELATED LITERATURE}

Traditional finance literature and practice focus on risk-return trade-off. There are numerous articles written about portfolio optimization by minimizing some quantitative measure of risk while maximizing returns. ${ }^{6}$ Non-financial risks are usually excluded from portfolio analysis. Even at the firm level, while calculating the expected value of the company, non-quantitative data about social or environmental aspects of the company business are usually exclud-

\footnotetext{
finance strategy and implementation of the action plan on financing sustainable growth is presented here: [https://ec.europa.eu/info/publications/sustainable-finance-renewed-strategy_en].

6 E. g. Konno, H. and Yamazaki, H.: Mean-Absolute Deviation Portfolio Optimization Model and Its Applications to Tokyo Stock Market, Management Science, 37(5), 1991, p. 519-531; Black, F. and Litterman, R., Global Portfolio Optimization, Financial Analysts Journal, 48(5), 1992, p. 28-43; Krokhmal, P., Palmquist, J. and Uryasev, S.: Portfolio optimization with conditional value-at-risk objective and constraints, Journal of Risk, (2), 2002, p. 43-68; DeMiguel, V., Garlappi, L., Nogales, F. J. and Uppal, R.: A Generalized Approach to Portfolio Optimization: Improving Performance By Constraining Portfolio Norms, Management Science, 55(5), 2009, p. 798-812; Kolm, P. N., Tutuncu, R. and Fabozzi, F. J.: 60 Years of portfolio optimization: Practical challenges and current trends, European Journal of Operational Research, 234(2), 2014, p. 356-371; Mansini, R., Ogryczak, W and Grazia Speranza, M.: Twenty years of linear programming based portfolio optimization, European Journal of Operational Research, 234(2), 2014, p. 518-535; Lwin, K. T., Qub, R. and MacCarthy, B. L.: Mean-VaR Portfolio Optimization: A Nonparametric Approach, European Journal of Operational Research, 260(2), 2017, p 751-766.
} 
ed. Contrary to that, sustainable finance aims to incorporate these social and environmental aspects in decision making. This is a common definition in literature, where there seems to be a rift between sustainable and traditional finance?

However, present-day social and ecological challenges imply that even in "traditional" financial analysis sustainability issues should be included. ${ }^{8}$ For example, will a long-term "traditional" investor into seaside resort disregard the consequences of rising sea levels or lack of local workforce? Or, put it differently, could a client sue an asset manager who failed to include rising sea levels in his investment analysis for such investment?

The question with finance today is not whether we should use sustainability concepts, but how to best integrate them. For the clients and regulators, another question is whether clients get what are is promised. Put it differently, is there a difference between two green or sustainable products although they are both marketed very similarly?

This is why we think sustainable finance should not be looked upon as being fundamentally different from "traditional" finance, but as only more observant about risk factors and long-run goals. This should not be a problem of finance, because "financial theory is indeed rooted in empirical realism and relies mainly on a deductive method of inquiry".

However, not all financial intermediaries include sustainability concepts in their investment process. Paetzold and Busch ${ }^{10}$ dwell on the problem of availability and accessibility of sustainable investments for private investors. By series of structured interviews, they conclude that private investors refrain from sustainable investments because their investment advisers poorly inform them.

E. g. Sandberg, J., Juravle, C., Hedesström, T. M. and Hamilton, I.: The Heterogeneity of Socially Responsible Investment, Journal of Business Ethics, 87(4), 2009, p. 519-533; Lagorarde-Segot, T.: Sustainable finance - A critical realist perspective, Research in International Business and Finance, 47(1), 2019, p. 1-9; Schoenmaker, D. and Schramade, W.: Principles of Sustainable Finance, Oxford: Oxford University Press, 2019.

8 E. g. Peylo, B. T.: A Synthesis of Modern Portfolio Theory and Sustainable Investment, Journal of Investing, 21(4), 2012, p. 33; Dobrovolskiene, N. and Tamošiuniene, R.: Sustainability-Oriented Financial Resource Allocation in a Project Portfolio through Multi-Criteria Decision-Making, Sustainability, 8(5), 2016, p. 1; Gomez-Bezares, F., Przychodzen, W. and Przychodzen, J.: Corporate Sustainability and ShareholderWealth - Evidence from British Companies and Lessons from the Crisis, Sustainability, 8(3), 2016., p. 2.

9 Lagorarde-Segot, T.: Sustainable finance - A critical realist perspective, Research in International Business and Finance, 47(1), 2019, p. 1.

10 Paetzold, F. and Busch, T.: Unleashing the Powerful Few: Sustainable Investing Behaviour of Wealthy Private Investors, Organization \& Environment, 27(4), 2014, p. 358. 
Having that in mind, the concept of sustainable investing is important because it stresses the need to include all important factors in the investment analysis.

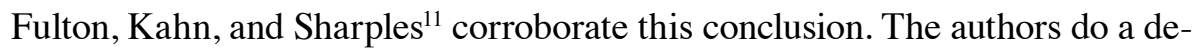
tailed survey of sustainability investing, checking the results of more than 100 academic studies on this topic. It seems that (at least in the past) companies that include sustainability concerns offered above-market returns. They find that $89 \%$ of the examined studies show that companies with higher ratings for economic, social, and governance (ESG) factors have outperformed the market. Besides, $85 \%$ of the studies show that such companies also outperform on accounting terms.

As for the returns of investment funds that follow so-called socially responsible investing practices, Fulton, Kahn, and Sharples ${ }^{12}$ find that $88 \%$ of the studies show funds exhibit mixed or neutral results vs. traditional funds. The authors explain that with the relatively imprecise definition of (early) sustainable investment strategies and prevalent use of exclusion strategies. In these strategies, some companies and industries are excluded, while no special effort is exercised towards integrating ESG factors into investment analysis. Fulton, Kahn, and Sharples ${ }^{13}$ go on and conclude that with excellent results for highly rated ESG companies, a strategy that selects such best in class ESG conscious companies should be superior.

\section{SUSTAINABLE INVESTMENTS NOW - BEFORE THE IMPLEMENTATION OF THE EC 2018 PLAN}

Even though the EC 2018 plan still has not been implemented, ${ }^{14}$ some informal (and very lax) norms for sustainable investments already exist. In order to distinguish between sustainable investments strategies and to be able to explain them to clients, the industry has accepted the classification system that divides sustainable investments in 7 major categories. ${ }^{15}{ }^{16}$ The categories themselves

11 Fulton, M., Kahn, B. M. and Sharples, C.: Sustainable Investing - Establishing Long-Term Value and Performance, [https://papers.ssrn.com/sol3/papers.cfm?abstract_id=2222740], 2012 , p. 8.

12 Ibid.

13 Ibid.

14 Formal implementation of EC 2018 plan starts on 10th of March 2020.

15 GSIA: Global Sustainable Investment Review, [http://www.gsi-alliance.org/wp-content/ uploads/2019/06/GSIR_Review2018F.pdf], 2018, p. 7.

16 EUROSIF: European SRI Study, [http://www.eurosif.org/wp-content/uploads/2016/11/ SRI-study-2016-HR.pdf], 2016, p. 9. 
do not seem to be strictly defined and could differ somewhat among the major regions in the world, but they are generally accepted.

The most prominent and most widely used strategy in sustainable investing is negative or exclusionary screening. This strategy excludes from a fund a portfolio of certain sectors, companies, or practices based on specific environmental, social, and governance (ESG) criteria. The other popular strategy is the ESG integration strategy, which aims at systematically integrating the consideration of ESG factors into financial analysis. Next, corporate engagement and shareholder action strategy aim to influence corporate behavior in line with the ESG guidelines. Similarly to the ESG integration strategy, normsbased screening strategy screens for investments based on compliance with international norms and standards issued by, for example, OECD, ILO, UN, and UNICEF. Positive or best in class screening strategy invests in companies based on positive ESG performance relative to peers. Sustainability-themed investing strategy invests in themes or assets that address specific sustainability issues like climate change, food or water scarcity, or renewable energy. Finally, impact or community investment strategy aims to solve targeted social or environmental problems.

The relatively vague nature of strategies reflects the challenges asset managers have while selecting and analyzing investments. However, the confusion for the end-user or consumer could be even more pronounced. Greenwashing, a practice where normal or even dirty activities are presented as being ecologically acceptable in order to sell them better, complicates the matters further. Without clearly defined rules or independent audits, it is difficult for consumers, but also for the asset manager, to select proper products or investments that will achieve proclaimed benefits for the community or the environment. For now, it seems that the market and increased demand for sustainable investments is a self-regulating mechanism that pushes companies to publish more data about their social impact.

Except for environmental and ethical issues, there is also a question of the performance of sustainable investments. It is possible that some sustainable strategies could deliver lower performance compared to "regular" investments. However, if in the investment analysis of different strategies sustainable component is included, then sustainable investments, in the end, might be more favorable. On the other hand, by failing to include the sustainability of investments in investment analysis, asset managers could be breaching their fiduciary duty towards clients. In a survey of fiduciary responsibility in the context of environmental, social, and governance factors UNEP, among others, presents: „There is no reason in law why trustees cannot consider social and moral criteria in addition to their usual criteria of financial returns, security and diversi- 
fication. This applies to trustees of all pension funds. ${ }^{17}$ However, UNEP also stresses the important aspect of informing clients about the investment process: "It is an obligation on pension fund trustees not simply a right or option to state in their Statement of Investment Principles what the fund's guidelines are on responsible investment and to what extent social, environmental or ethical considerations are taken into account.“"18

To summarize, it seems that there are three major issues linked to sustainable investments. The first one is linked to the definition of sustainability and classification of different sustainable investment strategies - it seems additional clarity could be beneficial. Second, there is a question of fiduciary duty, where it seems additional clarification and more information to the client would be beneficial for a fair long term relationship. Finally, but not least important, there is a question of data at the company level that is a basis for assessing environmental effects and defining investment strategy. European sustainable finance action plan (EC 2018 plan) aims to tackle all of the above-mentioned issues, at least in the EU.

\section{EU SUSTAINABLE FINANCE PACKAGE}

EC 2018 action plan on financing sustainable growth aims to "reorient capital flows towards a more sustainable economy". ${ }^{19}$ In order to do that, in the area of investment management, the regulation promotes investment advisors and asset managers to offer sustainable investment products. In this plan, the details of such products and investment managers' conduct while investing clients' funds are elaborated. However, as explained, the EC 2018 plan is not yet operational, but it is expected that it will be fully implemented in March 2021.

The implicit idea of the EC 2018 plan is to contribute to the sustainability of the EU's economy by promoting demand for sustainable investments. The EC 2018 plan implies that asset managers would demand more securities (both equities and bonds) that have sustainable features. On the other hand, securities issuers, if they want to remain investable, will aim to adopt sustainable principles. In that way, the majority of the economy would reorient towards (a more) sustainable way of doing business.

17 UNEP: Fiduciary responsibility - Legal and practical aspects of integrating environmental, social and governance issues into institutional investment, Asset Management Working Group of the United Nations Environment Programme Finance Initiative, [https://www.unepfi. org/fileadmin/documents/fiduciaryII.pdf], 2009, p. 15.

18 Ibid, p. 9.

19 EC: Renewed sustainable finance strategy and implementation of the action plan on financing sustainable growth, [https://ec.europa.eu/info/publications/sustainable-finance-renewed-strategy_en], 2018a. 
In terms of coverage, main requirements from the EC 2018 plan will be applicable to fund management companies, credit institutions, and investment companies when they manage portfolios, insurance companies that offer investment-based insurance products, institutions for occupational retirement provisions (IORPs), pension products providers and pan European pension product providers. As for the national pension products (for example so-called second and third pillar in Croatia), member states can opt in, but they are not required to. Finally, providers of EuSEF (European Social Entrepreneurship Funds) and EuVECA (European Venture Capital Fund) products are also covered by this regulation.

From the economic point of view, the exclusion of national pension savings plans is interesting. Pension plans, due to their long-term nature, usually dominate the financial landscape, so their inclusion would definitely be beneficial for the overall sustainability cause. However, abrupt a change in investment style could lead to significant short-term losses for investors, due to possible fire sale of non-compliant investments. In addition to that, national pension plans are often the result of a long-term compromise between social partners, and any sudden change, especially from the outside force (in this case from the EU level), could jeopardize such balance.

In terms of the legal implementation of the EC 2018 plan, the plan implies amending several important directives that govern day to day business for financial intermediaries $\left(\mathrm{MiFID}^{20}, \mathrm{UCITS}^{21}, \mathrm{AIFMD}^{22}\right.$, Solvency II $\left.{ }^{23}, \mathrm{IDD}^{24}\right)$. In addition to that, the new Sustainable Finance Disclosure Regulation introduces transparency and disclosure requirements for investment advisors and their products. Additionally, the Taxonomy Regulation aims to establish crite-

20 MiFID is a legislation that regulates financial markets and investor protection. Legal text of the Directive 2014/65/EU on markets in financial instruments and amending Directive 2002/92/EC and Directive 2011/61/EU: [https://eur-lex.europa.eu/legal-content/EN/TXT/?uri=CELEX:32014L0065].

21 For details on UCITS regulation please check European Commission web page on investment funds laws: [https://ec.europa.eu/info/business-economy-euro/growth-and-investment/ investment-funds_en].

22 Alternative Investment Fund Managers Directive. This directive governs the business for all non UCITS fund managers in the EU: [https://eur-lex.europa.eu/legal-content/EN/TXT/?uri=CELEX\%3A32011L0061].

23 This is the EU directive that sets rules for insurance and reinsurance business on common EU market: [https://eur-lex.europa.eu/legal-content/EN/TXT/?uri=CELEX\%3A32009L0138 \&qid=1606061423161].

24 This is the directive that aims to harmonize national rules regarding insurance and reinsurance distribution within the EU: [https://eur-lex.europa.eu/legal-content/EN/TXT/?uri=CELEX\%3A32016L0097\&qid=1606061525796.]. 
ria for classifying economic activity in terms of sustainability and introduces additional disclosure requirements for sustainable products.

Regarding the insurance business, the EC 2018 plan tackles two major issues. One is related to the distribution of insurance products to clients (that is regulated via IDD). This is mostly targeted towards the life insurance business, where clients buy insurance products that also have an investment component. For that reason, EC 2018 will ask for an explanation of sustainability risks. In addition to that, changes to the Solvency II framework request formal integration of sustainability risks into insurance companies' risk management, actuarial function, and investments.

Legal changes set out in the directives above are the basis for doing business in the distribution of investment funds and insurance but they also govern the behavior of investment professionals, insurance managers, and actuaries while they perform their duties for their clients or while managing insurance undertakings' assets. However, it is important to say that the whole regulation, especially the part that is oriented towards selling products to clients has complied or explained tone. This means that the service providers are free to choose whether they will implement sustainability assessment into their products or not. If they do not implement it, they will have to state that fact clearly and visibly to customers. It seems that the idea of the EC 2018 plan was realized in a "name and shame" fashion. The intermediaries that decide to skip implementing EC 2018 plan will be clearly designated which could influence their market position, especially having in mind current demand trends for sustainable investments.

Yet, the effects of "name and shame" policies are expected to be different in various markets. If the major investment managers accept the plan, possible pockets of noncompliance could remain only on smaller markets, not covered by the biggest European asset managers. There is some evidence that the investment management companies' associations accept and welcome the change. For example, on the topic of renewed sustainable finance strategy EFAMA $^{25}{ }^{26}$ states: "As the voice of the European investment management industry, we welcome the launch of such a comprehensive consultation, on a topic that remains rightly very high on the EU agenda". Similarly, BlackRock, the world's largest asset manager has "unveiled sweeping changes in an effort

25 EFAMA is the biggest European investment management industry association. Please check [https://www.efama.org] for more details.

26 EFAMA: Consultation on the Renewed Sustainable Finance Strategy - EFAMA hopes for a more holistic and consistent approach, [https://www.efama.org/Documents/20-4018_ EFAMA\%20response\%20to\%20Renewed\%20Sustainable\%20Finance\%20Strategy.pdf], 2020, p. 1. 
to position itself as a leader in sustainable investing". ${ }^{27}$ From all of this, it seems that the EC 2018 plan could drive at least part of the investments in a sustainable direction.

\section{ANY ROOM FOR SUSTAINABILITY? POTENTIAL FOR IMPLEMENTING SUSTAINABLE INVESTMENTS IN THE CROATIAN NON-BANK FINANCIAL SECTOR}

The primary idea of the EC 2018 plan is to reorient capital flows towards a more sustainable economy. By analyzing the structure of the financial system and investment strategy of financial intermediaries, we will be able to better gauge the possibility for promoting sustainable investments and potential obstacles to the implementation of such policies. To evaluate the effects of the EC 2018 plan on the Croatian economy, we need to assess the (financial and investment) importance of the sectors influenced by the new regulation for the economy and the possible impact of the new way of doing business. To do that, we will first look at the size and the composition of investment portfolios managed by those intermediaries. Potential switch towards more sustainable investments except for higher demand (that is evident here) also has to come from financial intermediaries that start offering new, sustainable products and by doing so, creating demand for products (securities) that include sustainability issues in their business plans.

In this paper, we do not deal with the banking sector, but with non-bank financial intermediaries that are actively managing their clients' portfolios. Banks are important as savings institutions and distributors of financial products, but in Croatia, they usually do not create their own investment products (besides savings).

According to $\mathrm{Hanfa}^{28}$ and as shown in Table 1, the financial sector in Croatia is dominated by banks that hold $68 \%$ of the total assets of all financial intermediaries. Non-bank financial intermediaries manage remaining $32 \%$ the of assets. In terms of potential economic impact, total assets of non-bank financial intermediaries that could theoretically be subject to sustainable finance regulation are $47 \%$ of Croatian gross domestic product (GDP).

\footnotetext{
27 Henderson, R., Nauman, B. and Edgecliffe-Johnson, A.: BlackRock shakes up business to focus on sustainable investing, Finacial Times, January 14th, 2020, [https://www.ft.com/ content/57db9dc2-3690-11ea-a6d3-9a26f8c3cba4.].

28 Hanfa: Odabrani pokazatelji sektora financijskih usluga - Standardni prezentacijski format, [https://www.hanfa.hr/media/5212/spf_listopad_27112020.pdf], 2020,p. 8.
} 
Table 1. Relative and absolute share of various financial intermediaries on Croatian market

\begin{tabular}{|l|r|r|r|r|}
\hline Type of intermediary & Number & \multicolumn{1}{|c|}{$\begin{array}{c}\text { Total assets } \\
\text { (HRK } \\
\text { billion) }\end{array}$} & \multicolumn{1}{c|}{$\begin{array}{c}\text { Share (in } \\
\text { total) }\end{array}$} & \multicolumn{1}{c|}{\begin{tabular}{c}
\multicolumn{1}{c|}{ Share (in } \\
GDP)
\end{tabular}} \\
\hline $\begin{array}{l}\text { Banks, housing savings banks and credit } \\
\text { unions }\end{array}$ & 44 & 450,3 & $68,1 \%$ & $111,9 \%$ \\
\hline Pension Funds & 40 & 119,1 & $18,0 \%$ & $29,6 \%$ \\
\hline Insurance and reinsurance undertakings & 15 & 46,6 & $7,1 \%$ & $11,6 \%$ \\
\hline Investment Funds & 136 & 21,9 & $3,3 \%$ & $5,4 \%$ \\
\hline Leasing societies & 15 & 20,7 & $3,1 \%$ & $5,2 \%$ \\
\hline Other & 33 & 1,7 & $0,3 \%$ & $0,4 \%$ \\
\hline
\end{tabular}

Source: Hanfa and authors' calculations

The most important non-bank financial intermediaries in Croatia are pension funds, which hold $57 \%$ of the total non-bank financial intermediaries' assets. Obligatory pension funds that are by far the largest asset managers invest most of their assets to government bonds (68\%). Shares constitute $17 \%$ of their portfolios (of which $10 \%$ domestic and $7 \%$ foreign shares). In total, voluntary pension funds (open and close-ended) have a similar investment strategy, but with more exposure towards equities, i.e. more risk. The share of government bonds for these intermediaries stands at 57\% (53\% domestic and 5\% foreign government bonds) and the share of equity investments is at $23 \%$ (16\% domestic and $7 \%$ foreign shares).

However, it is important to note that directives that cover EC 2018 plan do not affect obligatory pension funds in Croatia, as was discussed earlier.

Investment funds hold $10 \%$ of the total non-bank financial intermediaries' assets. Undertakings for collective investment in transferable securities, commonly known as UCITS funds, constitute the majority of fund investments in Croatia. As a group, they also invest mostly in to government bonds, although there is a wide difference in the share of bonds, equities, and other asset classes between various fund types. In total, government bonds are 63\% of their assets (44\% are domestic and 19\% foreign bonds). Shares stand at $9 \%$ of their total investments, of which $6 \%$ foreign and $3 \%$ domestic stocks.

Alternative funds, which are oriented toward professional investors and affluent individuals, are rather a diverse category that encompasses funds that invest 
in listed securities, funds that are oriented towards private equity projects and SME investments. Specific funds are often oriented towards only a handful of clients. Besides, on Croatian market entities linked to the government (like HBOR - Croatian Bank for Reconstruction and Development) and obligatory pension funds play a dominant role on the market as investors. In recent years, EIF (European Investment Fund) emerged as an important investor as well.

Finally, insurance companies hold $22 \%$ of the total non-bank financial intermediaries' assets. A small part (about 6\%) of insurance companies' investments is made for insurance policy holders where clients bear the investment risk (product often called unit-link insurance). These investments are sold as investment products and in the future, due to the EC 2018 plan, sustainability considerations will have to be directly addressed while selling such products.

In terms of asset allocation, insurance companies in Croatia are on average conservative, but less than pension funds. At the end of June 2020, 67\% of investments were in fixed income securities, loans were next with $11 \%$ share, followed by real estate with $8 \%$ share. Direct investment in equity equals $6 \%$ of the investment portfolio, while investment funds compromise $5 \%$ of their portfolio.

If we look at the portfolio composition for all these financial intermediaries, the share of government bonds stands as a major investment, with equities having a relatively minor share. Many of the intermediaries holding a share of the portfolio in government bonds have an obligation to do so (obligatory and voluntary pension funds). In other instances, exposure towards central government caries preferential treatment (insurance undertakings) due to lower capital requirements for investing in such assets Having this in mind, we can conclude that channel of influence where intermediaries exert some kind of influence towards government is of limited scope, even if the EC 2018 plan were to be implemented fully. However, on the common European market, it could happen that some countries start issuing so-called "green bonds" whose proceeds are invested in sustainable projects. It is expected, given the current demand for sustainable investments and the EC 2018 sustainable finance plan that this type of bonds would be sold with lower required yields than "regular" ones. As a result, the central government could have an incentive to issue such bonds, satisfying the demand for such products by non-bank financial intermediaries.

Conversely to this high share of government bond investments, as we have shown above, the share of equity investments is unfortunately rather limited. Through equity investments, financial intermediaries can have the biggest impact on the sustainability of the economy, as firms are the primary driving force of the domestic economy and they influence the economy through their 
production practices, workplace practices, and practices they require from their suppliers. Our primary concerns here are domestic investments. Total domestic equity investments by intermediaries covered above are estimated to be HRK 18.1 billion or $4 \%$ of GDP. ${ }^{29}$ The biggest share of direct equity investments is with the pension funds, they hold HRK 12.7 billion or 3\% of GDP of domestic equity investment. To get the complete picture, we also compare these numbers to total the market capitalization of domestic listed equity, which equaled HRK 130.1 billion. ${ }^{30}$ In that respect, domestic pension and investment funds hold about $14 \%$ of total Croatian listed equity.

Even if equity investments are limited, the impact of adopting sustainable policies at the company level could be significant. Listed companies are usually big and important players in the domestic economy. Change of policies towards a more sustainable way of doing business, except direct effects, could have multiplicative effects through a network of suppliers and customers. This catalyst activity would be even more pronounced if some major companies with significant market share and public recognition would adopt sustainable policies.

For example, the top 10 Croatian pension funds domestic equity investments (these companies represent $80 \%$ of their total domestic investments) have combined annual sales equal to $17 \%$ of GDP. Put it differently, these companies represent roughly $17 \%$ of the domestic economy and form an important base for potential sustainability practices.

Even though pension funds hold a significant share of the total listed equity in Croatia, the fact that obligatory pension funds, which are the most important type of pension funds, are not covered by the EC 2018 plan, diminishes possibilities to push listed companies in the sustainable business direction. However, if pension funds adopt EC 2018 plan, the situation could be more favorable.

Similarly to Croatia, in many other EU member states the category of pension and insurance savings is the most important part of household wealth, especially if we exclude bank deposits (Figure 1). This again corroborates the fact that including pension savings would be an important way to increase the effectiveness of the EC 2018 plan.

\footnotetext{
29 This number is based on data published by Hanfa in monthly reports for pension funds, UCITS and alternative funds. The data for pension funds and UCITS funds are detailed so it is possible to discern share of domestic equity investments. The data on alternative funds is scarce, so we estimate the share of domestic equity by fund type in range from $50-100 \%$. On that, we add data on equity investments by insurance undertakings that are published in Hanfa 2020. Again, here the data is rather scarce, so we estimate $90 \%$ of equity investments are domestic equity investments.

30 This is end of October 2020 data from Zagreb Stock Exchange: [https://zse.hr/hr/trzisna-kapitalizacija/40].
} 
Figure 1. Households' financial assets as a percentage of GDP (data as of end March 2020)

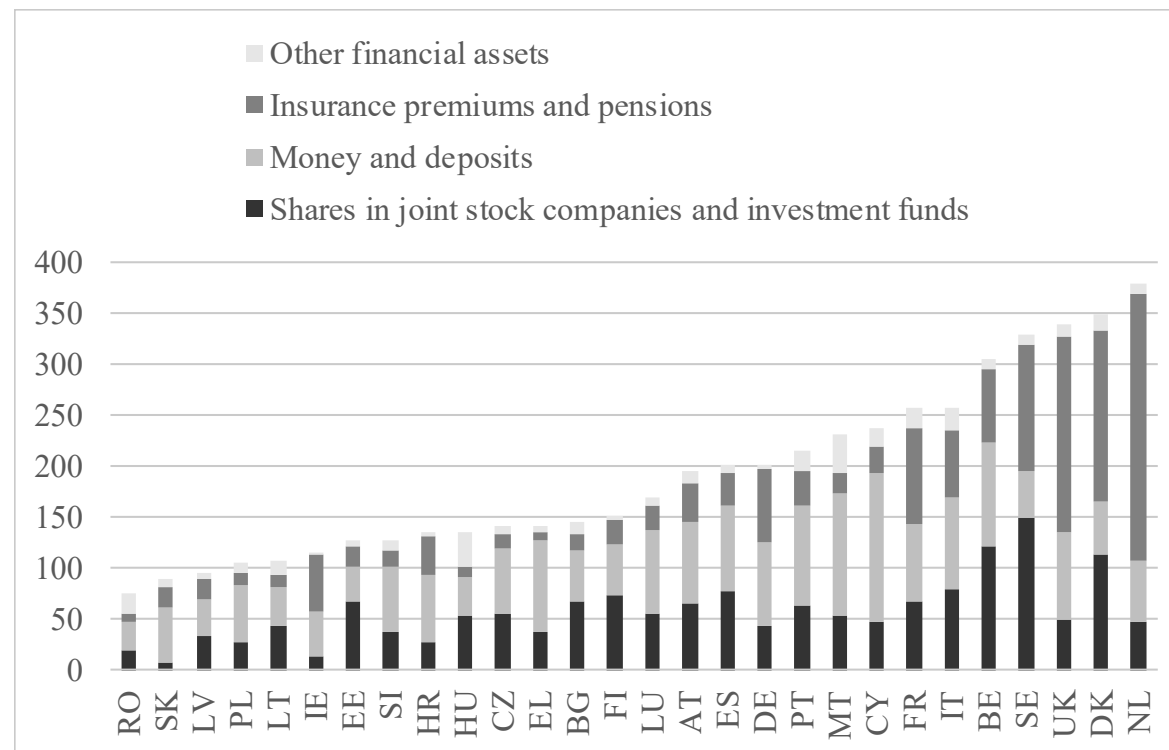

Source: Eurostat, quarterly financial accounts.

\section{SUPPLY-SIDE - DO COMPANIES WANT TO CHANGE AND HOW FAST CAN THEY CHANGE?}

Until now, we have dealt with demand-side for sustainable investments, primarily asset managers as the EC 2018 plan puts them into the foreground. However, asset managers will not be able to acquire sustainable investments if companies do not adapt to new requirements. In the first instance, this means publishing enough data so that the asset managers can perform the required analyses. However, requirements for such non-financial data have not been integrated into EC 2018 plan until now. This could pose a significant problem for plan implementation as asset managers (as primary targets of EC 2018 plan) will not be able to assess companies' sustainability standing.

EFAMA, as an industry organization for the European fund management industry, also stresses the need for (more) corporate reporting about sustainability risks. ${ }^{31}$ They find significant gaps in available data and conclude that data

\footnotetext{
31 EFAMA: Consultation on the Renewed Sustainable Finance Strategy - EFAMA hopes for a more holistic and consistent approach, [https://www.efama.org/Documents/20-4018_EFAMA\%20 response\%20to\%20Renewed\%20Sustainable\%20Finance\%20Strategy.pdf], 2020, p. 2.
} 
gaps are a key impediment in the realization of the full potential of the EC 2018 plan. As a result, although they support the EC 2018 plan, they advise the prolongation of the initial implementation deadline and a more gradual approach that would also encompass changes in corporate non-financial reporting requirements where sustainability issues are reported.

The lack of available data at present moment is certainly an issue, although many companies already report on some of the sustainable concerns. This could be especially problematic in smaller markets, like Croatian, where companies do not see the stock exchange as a major factor or important source of financing.

To assess the Croatian situation, we have used National Review Report on Sustainability Reporting. ${ }^{32}$ This report in April 2015 survived 1400 companies of all sizes throughout Croatia via email to assess companies' attitudes towards corporate social responsibility (CSR) issues. Although the response ratio for this survey was $7 \%$, the results are still very interesting as this is the only comprehensive study done on this topic in Croatia. Results show that large companies and joint-stock companies had a much larger interest in surveys than micro and small companies, which is indicated by their over-representation in the sample. This is to be expected as larger companies have more resources in order to deal with this type of issue. This also implies that when analyzing this survey, results primarily indicate attitudes of medium-sized and large companies.

Further, the National Review Report on Sustainability Reporting survey data shows that Croatian companies are overall familiar with the corporate social responsibility concept and almost all large companies report on CSR issues. In addition to that, many companies (25\%) have already included CSR concepts on a relatively high level in their day-to-day operations. Still, the survey was done in 2015 when exact proportions of reporting requirements needed to assess sustainability at the company level were still unknown.

The great majority (92\%) of respondents are familiar with the corporate social responsibility concept. A bit lower, although still high, the proportion of the respondents' companies actually implements CSR (78\%). Even if the criteria for the implementation of CSR are subjective, this number still indicates a high potential for CSR reporting. Probably around $25 \%$ of the companies have firmly implemented CSR policies and would easily adapt to more reporting requirements by investors. The proportion of respondents that have designated departments in charge of CSR activities indicates this (25\%).

32 Croatian Employers' Association, Corporate social responsibility for all - National Review Report on Sustainability Reporting, Turkish Confederation of Employer Associations (TISK) with the Project Partner Croatian Employers' Association, 2015. 
Table 2. Disclosure of non-financial information according to the company size (in \%)

\begin{tabular}{|l|c|c|c|c|}
\hline $\begin{array}{l}\text { Disclosure of non-financial } \\
\text { information }\end{array}$ & Micro & Small & Medium-sized & Large \\
\hline Yes & 12.1 & 40.9 & 39.1 & 92.0 \\
\hline No, but prepares to do so & 9.1 & 13.6 & 13.0 & 8.0 \\
\hline No & 75.8 & 40.9 & 43.5 & 0 \\
\hline No answer & 3.0 & 4.5 & 4.3 & 0 \\
\hline
\end{tabular}

Source: Croatian Employers' Association (2015)

Another important topic is activities related to disclosure. Overall, $44 \%$ of the respondents disclose non-financial information and $11 \%$ prepares to do so. This is significantly higher for large companies where $92 \%$ of the respondents publish and an additional 8\% plans to publish non-financial information (Table 2). Again, the survey did not go into detail about the adequacy of the reported data.

Presented survey results can form a basis for cautious optimism. It seems that medium-sized and large companies especially could form a basis for introducing more sustainability-oriented policies. Following a push from the demand side (from investors), these companies probably could adapt and report in line with new sustainability requirements. However, on a market like Croatian that is very bank-centric, the question remains is this initial push from the investor side possible due to the relatively small share of equity financing in the total financing mix. Finally, as non-financial reporting requirements are currently not streamlined to EC 2018 plan implementation, it would be worthwhile to motivate listed companies for additional sustainability reporting. A natural way to do this would be via stock exchange rules - for example, companies listed in higher quotations could be required to lead the way by publishing more data. Naturally, there should also be some standardization of the published data to make it comparable.

\section{CONCLUSION}

The sustainable finance plan (EC 2018) European Union has enacted is an important step that shows policymakers' willingness to try to tackle climate change. Whether this plan will be successful or not depends on its practical implementation. In addition to several important implementing acts of the overall plan that are still in discussion, the overall success will depend on the reception of the plan by the consumers, asset management, and insurance industry. 
The speed (and overall success) of the change will however depend not only on the implementation of new disclosure rules but also on modification of overall business practices. This is why new rules must be clear and without any possibility of greenwashing practices.

As for the individual member state, The EC 2018 plan should be looked upon as a starting point because some important details are left for the national state to tackle. For example, pension savings, which represent the majority of household savings across the EU (especially if you exclude bank deposits), are not covered by the EC 2018 plan. This is the opportunity for the member states to introduce sustainability provisions into their national legislation as they see fit, without outside pressure from the EU.

Companies and especially listed companies are at the center of the sustainability drive. Asset managers will not be able to acquire sustainable investments if companies do not adapt to new requirements. Except for publishing more data so that asset managers can perform required analyses this also means changing (more or less) how they operate.

However, even the requirements for publishing non-financial data are not integrated into EC 2018 plan. This could pose a significant problem for plan implementation. Again, member states should act as a catalyst here. By issuing either hard or soft regulations, member states can direct companies towards progressive practices.

What will happen with companies that do not want to change? Having in mind growing awareness and growing demand for sustainable investment products that will be further strengthened by EC 2018 plan, those companies will probably be avoided by investors. For national financial markets, this could mean that they will become irrelevant and slowly die out. A similar future will happen if the companies drag their legs while adapting to the new environment. Due to the nature of regulation, first-comers will have a significant advantage vs. the rest, because the demand from asset managers will be higher (due to scarcity of available investment options at the beginning of implementation). Such a situation could prove to be ideal for putting a company (or a country) on a global investment chart.

Having that in mind, sustainable finance could be an excellent opportunity for a country like Croatia, not only for gradually transforming its economy but also to position itself on a global investment map. 


\section{LITERATURE}

1. Black, F. and Litterman, R. (1992), Global Portfolio Optimization, Financial Analysts Journal, Vol. 48, No 5, p. 28-43.

-DOI: https://doi.org/10.2469/faj.v48.n5.28

2. Croatian Employers' Association (2015), Corporate social responsibility for all - National Review Report on Sustainability Reporting, Turkish Confederation of Employer Associations (TISK) with the Project Partner Croatian Employers' Association

3. DeMiguel, V., Garlappi, L., Nogales, F. J. and Uppal, R. (2009), A Generalized Approach to Portfolio Optimization: Improving Performance by Constraining Portfolio Norms, Management Science, Vol. 55, No. 5, p. 798-812.

-DOI: https://doi.org/10.1287/mnsc.1080.0986

4. Dobrovolskiene, N. and Tamošiuniene, R. (2016), Sustainability-Oriented Financial Resource Allocation in a Project Portfolio through Multi-Criteria Decision-Making, Sustainability, Vol. 8, No. 5, p. 1-18.

-DOI: https://doi.org/10.3390/su8050485

5. EC (2018), Action Plan: Financing Sustainable Growth, [https://eur-lex.europa.eu/ legal-content/EN/TXT/PDF/?uri=CELEX:52018DC0097\&from=EN]

6. EC (2018a), Renewed sustainable finance strategy and implementation of the action plan on financing sustainable growth, [https://ec.europa.eu/info/publications/ sustainable-finance-renewed-strategy_en]

7. EFAMA (2020), Consultation on the Renewed Sustainable Finance Strategy EFAMA hopes for a more holistic and consistent approach, [https://www.efama. org/Documents/20-4018_EFAMA\%20response\%20to\%20Renewed\%20Sustainable\%20Finance\%20Strategy.pdf]

8. EUROSIF (2016), European SRI Study, [http://www.eurosif.org/wp-content/uploads/2016/11/SRI-study-2016-HR.pdf ]

9. Fulton, M., Kahn, B. M. and Sharples, C. (2012), Sustainable Investing - Establishing Long-Term Value and Performance, [https://papers.ssrn.com/sol3/papers. cfm?abstract_id=2222740]

10. Gomez-Bezares, F., Przychodzen, W. and Przychodzen, J. (2016), Corporate Sustainability and ShareholderWealth - Evidence from British Companies and Lessons from the Crisis, Sustainability, Vol. 8, No. 3, p. 1-22.

-DOI: https://doi.org/10.3390/su8030276

11. GSIA (2018), Global Sustainable Investment Review, [http://www.gsi-alliance. org/wp-content/uploads/2019/06/GSIR_Review2018F.pdf ]

12. Hanfa (2020), Odabrani pokazatelji sektora financijskih usluga - Standardni prezentacijski format,[https://www.hanfa.hr/media/5212/spf_listopad_27112020.pdf] 
13. Henderson, R., Nauman, B. and Edgecliffe-Johnson, A.: BlackRock shakes up business to focus on sustainable investing, Finacial Times, January 14th, 2020, [https://www.ft.com/content/57db9dc2-3690-11ea-a6d3-9a26f8c3cba4].

14. Kolm, P. N., Tutuncu, R. and Fabozzi, F. J. (2014), 60 Years of portfolio optimization: Practical challenges and current trends, European Journal of Operational Research, Vol. 234, No. 2, p. 356-371.

-DOI: https://doi.org/10.1016/j.ejor.2013.10.060

15. Konno, H. and Yamazaki, H. (1991), Mean-Absolute Deviation Portfolio Optimization Model and Its Applications to Tokyo Stock Market, Management Science, Vol. 37, No. 5, p. 519-531.

-DOI: https://doi.org/10.1287/mnsc.37.5.519

16. Krokhmal, P., Palmquist, J. and Uryasev, S. (2002), Portfolio optimization with conditional value-at-risk objective and constraints, Journal of Risk, Vol. 4, No. 2, p. 43-68.

-DOI: https://doi.org/10.21314/JOR.2002.057

17. Lagorarde-Segot, T. (2019), Sustainable finance - A critical realist perspective, Research in International Business and Finance, Vol 47, No. 1, p. 1-9.

-DOI: https://doi.org/10.1016/j.ribaf.2018.04.010

18. Lwin, K. T., Qub, R. and MacCarthy, B. L. (2017), Mean-VaR Portfolio Optimization: A Nonparametric Approach, European Journal of Operational Research, Vol. 260, No. 2, p 751-766.

-DOI: https://doi.org/10.1016/j.ejor.2017.01.005

19. Mansini, R., Ogryczak, W and Grazia Speranza, M. (2014), Twenty years of linear programming based portfolio optimization, European Journal of Operational Research, Vol. 234, No. 2, p. 518-535.

-DOI: https://doi.org/10.1016/j.ejor.2013.08.035

20. Paetzold, F. and Busch, T. (2014), Unleashing the Powerful Few: Sustainable Investing Behaviour of Wealthy Private Investors, Organization \& Environment, Vol. 27, No. 4, p. 347-367.

-DOI: https://doi.org/10.1177/1086026614555991

21. Peylo, B. T. (2012), A Synthesis of Modern Portfolio Theory and Sustainable Investment, Journal of Investing, Vol. 21, No. 4, p. 33-46

-DOI: https://doi.org/10.3905/joi.2012.21.4.033

22. Sandberg, J., Juravle, C., Hedesström, T. M. and Hamilton, I. (2009), The Heterogeneity of Socially Responsible Investment, Journal of Business Ethics, Vol. 87, No. 4, p. 519-533.

-DOI: https://doi.org/10.1007/s10551-008-9956-0

23. Schoenmaker, D. and Schramade, W. (2019), Principles of Sustainable Finance, Oxford: Oxford University Press. 
24. UBS (2017), Millennials - the global guardians of capital, UBS Chief Investment Office, Wealth Management white paper, [https://www.ubs.com/global/ en/wealth-management/chief-investment-office/market-insights/digital-disruptions/2017/millennials.html]

25. UNEP (2009), Fiduciary responsibility - Legal and practical aspects of integrating environmental, social and governance issues into institutional investment, Asset Management Working Group of the United Nations Environment Programme Finance [Initiative, https://www.unepfi.org/fileadmin/documents/fiduciaryII.pdf] 